\title{
SURVEI TERHADAP KEPUASAN MAHASISWA PADA KUALITAS LAYANAN DI STT SIMPSON UNGARAN, SEMARANG, JAWA TENGAH
}

\author{
I Putu Ayub Darmawan \\ putuayub@sttsimpson.ac.id \\ Program Studi Pendidikan Agama Kristen \\ Sekolah Tinggi Teologi Simpson Ungaran \\ Edi Sujoko \\ elead_ethnan@yahoo.co.id \\ Program Studi Pendidikan Agama Kristen \\ Sekolah Tinggi Teologi Simpson Ungaran
}

\begin{abstract}
ABSTRAK
Penelitian ini mengkaji kualitas layanan yang disediakan oleh STT Simpson, Kabupaten Semarang dan pengaruhnya terhadap tingkat kepuasan mahasiswa. Lebih khusus lagi, penelitian ini bertujuan untuk mengetahui pengaruh tangibles (keberwujudan), reability (kehandalan), responsiveness (ketanggapan), assurance (jaminan) dan empathy (ketulusan) terhadap kepuasan mahasiswa.Penelitian ini termasuk penelitian kuantitatif khususnya survei. Populasi sebagai wilayah generalisasi yang terdiri atas 75 responden. Mengingat jumlah mahasiswa STT Simpson yang tidak terlalu banyak maka dalam penelitian ini tidak akan menggunakan sampel melainkan akan diambil seluruhnya atau menggunakan populasi. Karena variabel yang diteliti dalam penelitian ini adalah kepuasan mahasiswa maka ada satu instrument yang dibuat yaitu instrumen untuk mengukur kepuasan pelayanan mahasiswa. Skala pengukuran yang akan digunakan dalam penelitian ini adalah skala Likert dengan skala interval 1 sampai 5. Hasil penelitian ini menyimpulkan bahwa: (1) Kualitas layanan yang berwujud fisik secara keseluruhan memuaskan bagi mahasiswa STT Simpson, (2) Kualitas layanan Kehandalan secara keseluruhan sangat memuaskan bagi mahasiswa STT, (3) Kualitas layanan yang berupa daya tanggap STT Simpson memuaskan mahasiswa, (4) Kualitas layanan yang berupa jaminan secara keseluruhan sangat memuaskan bagi mahasiswa STT Simpson, (5) Kualitas layanan rasa perduli dan perhatian secara keseluruhan memuaskan mahasiswa STT Simpson.
\end{abstract}

Kata kunci: kualitas pelayanan, kepuasan mahasiswa

\section{PENDAHULUAN}

Bertambahnya jumlah Sekolah Tinggi Teologi (STT) pada masa kini membuat persaingan antar STT menjadi semakin ketat. Situasi tersebut menuntut STT memberikan pelayanan yang berkualitas agar dapat memenangkan persaingan yang dihadapi. Sebagai pemberi jasa dalam bidang pendidikan, STT dituntut untuk dapat memberikan pelayanan yang akan meningkatkan kepuasan mahasiswa, yang pada akhirnya menciptakan loyalitas yang tinggi. Penyelenggaraan pendidikan selayaknya mencermati kualitas pelayanan sebab kegiatan pendidikan tidak hanya berorientasi pada hasil akhir proses 
pendidikan, tetapi juga melalui pembuktian akuntabilitas yang baik meliputi jaminan kualitas (quality assurance), pengendalian kualitas (quality control), dan perbaikan kualitas (quality improvement) (Badan Akreditasi Nasional Perguruan Tinggi, 1998 dlm. Rinala 2013).Untuk mencapai hasil akhir yang maksimal, diperlukan peningkatan kualitas secara terus menerus sebab peningkatan kualitas merupakan satu langkah menuju kesempatan dan mencapai sasaran dari kegagalan nol (Syafaruddin, 2012:35).

Menurut Sallis (2012:45) peningkatan kualitas atau mutu menjadi penting bagi institusi yang digunakan untuk memperoleh kontrol yang lebih baik melalui dirinya sendiri. Sementara keunggulan suatu produk jasa adalah tergantung dari keunikan dan kualitas yang diperhatikan oleh jasa tersebut apakah sudah sesuai dengan harapan dan keinginan konsumen, dalam hal ini adalah mahasiswa (Syamsi, 2008:23). Kualitas sekolah seringkali menjadi sebuah pembeda bagi sekolah tersebut dengan sekolah yang lain dan akan menjadi daya tarik bagi pengguna jasa pendidikan dan kebanggaan bagi mahasiswanya.

STT Simpson sebagai organisasi publik seharusnya memberikan pelayanan akademik yang berkualitas. STT Simpson merupakan salah satu lembaga pendidikan tinggi teologi swasta yang dikelola oleh Badan Pengurus Pusat Gereja Kemah Injil Indonesia. Sebagai lembaga pendidikan teologi, STT Simpson diharapkan menyelenggarakan Lembaga Pendidikan Tinggi Teologi Injili yang berkualitas, mengutamakan intelektualitas dengan kualitas unggul, menjadi wadah pelaksanaan penelitian dan pengembangan ilmu teologi sesuai dengan tuntutan zaman, mempersiapkan tenaga yang terampil dalam pelayanan di gereja dan masyarakat, serta melaksanakan pengabdian pelayanan di gereja dan masyarakat.

STT Simpson mengelola dua program studi (Prodi) yaitu Prodi S-1 Teologi/ Kependetaan dan Prodi S-1 Pendidikan Agama Kristen. Untuk menjalankan kedua Prodi tersebut STT Simpson mengajukan ijin operasional pada Kementrian Agama Cq. Direktur Jenderal Bimbingan Masyarakat Kristen. Sementara untuk memperoleh gambaran mutu STT Simpson mengajukan dan memperoleh akreditasi untuk kedua Prodi tersebut pada Badan Akreditasi Nasional Perguruan Tinggi (BAN-PT). Status akreditasi merupakan gambaran kinerja dan mutu perguruan tinggi, serta relevansi penyelenggaraan suatu program studi.

Pada semester Gasal tahun ajaran 2016/2017 jumlah mahasiswa STT Simpson sekitar 93 mahasiswa. Untuk menunjang kegiatan proses pendidikan, STT Simpson didukung oleh 12 dosen tetap, 6 dosen tidak tetap, dan 7 orang tenaga administrasi. Dengan jumlah mahasiswa yang tidak terlalu banyak seharusnya akan lebih mudah dalam memberikan pelayanan. Untuk itu sebagai bentuk evaluasi perlu disurvei sejauhmana kepuasan mahasiswa terhadap kualitas pelayanan STT Simpson kepada mahasiswa. Dengan demikian akan diperoleh sebuah gambaran yang akan mendukung usaha peningkatan pelayanan akademik STT Simpson.

Penelitian dengan topik yang sama pernah dilakukan oleh I Nyoman Rinala dan rekan-rekannya pada tahun 2013 dengan judul penelitian "Pengaruh Kualitas Pelayanan Akademik Terhadap Kepuasan dan Loyalitas Mahasiswa Pada Sekolah 
Tinggi Pariwisata Nusa Dua Bali”. Hasil penelitian tersebut dipublikasikan dalam eJournal Program Pascasarjana Universitas Pendidikan Ganesha Program Studi Administrasi Pendidikan, Volume 4 Tahun 2013. Penelitian yang dilakukan oleh Rinala dilakukan di Bali pada Sekolah Tinggi Pariwisata (STP) Nusa Dua. Sekolah tersebut merupakan Unit Pelaksana Teknis (UPT) pendidikan tinggi kedinasan di lingkungan Kementerian Pariwisata dan Ekonomi Kreatif yang berada dan bertanggung jawab langsung kepada Menteri Pariwisata dan Ekomomi Kreatif (Rinala 2013). Sebagai pendidikan tinggi kedinasan, STP Nusa Dua dengan sumber daya yang memadai selayaknya memberikan pelayanan yang terbaik. Perbedaan antara penelitian yang dilakukan oleh Rinala dengan penelitian yang akan dilakukan penulis adalah jumlah prodi, tempat penelitian, jumlah mahasiswa, dan lembaga penyelenggara. Jika STP Nusa Dua menyelenggarakan 17 Prodi sehingga tingkat kerumitan pemberian pelayanan cukup tinggi sementara STT Simpson hanya menyelenggarakan 2 Prodi. Penelitian Rinala dilakukan di Nusa Dua Bali, sementara penelitian ini akan dilakukan di STT Simpson Ungaran Semarang. Jumlah mahasiswa di STT Simpson tidak sebesar jumlah mahasiswa di STP Nusa Dua Bali. Penyelenggara STP Nusa Dua adalah pemerintah khususnya Kementerian Pariwisata dan Ekonomi Kreatif sementara penyelenggara STT Simpson Ungaran adalah gereja atau swasta. Dengan situasi tersebut maka akan ada perbedaan dalam berbagai hal.

Miyono (2011:148) mengungkapkan bahwa kunci keberhasilan institusi pendidikan dalam menghadapi persaingan memperebutkan resources, disebabkan oleh pendekatan dan pemahaman paradigma pelanggan yang tepat, dinamis dan lebih luas, sehingga sekolah dituntut untuk lebih aktif dalam mengumpukan input yang berkualitas dalam rangka kompetisi. Untuk memenangkan kompetisi, input yang diperoleh kemudian dijadikan acuan untuk meningkatkan kualitas layanannya. Oleh sebab itu perlu dilakukan penelitian untuk dapat memperoleh input yang berkualitas sehingga peningkatan kualitas menjadi lebih baik.

Rumusan masalah dalam penelitian ini adalah sejauhmana kepuasan mahasiswa terhadap kualitas kualitas pelayanan STT Simpson kepada mahasiswa? Sementara tujuan penelitian ini untuk mengetahui kepuasan mahasiswa terhadap kualitas layanan kepada mahasiswa STT Simpson. Secara teoritis penelitian ini diharapkan memberi kontribusi untuk meningkatkan ilmu pengetahuan dalam bidang pendidikan, khususnya manajemen pendidikan. Sementara manfaat secara praktis yang dapat disumbangkan dari penelitian ini adalah untuk memberikan masukan untuk perbaikan pelaksanaan kebijakan dalam peningkatan kualitas pelayanan di STT Simpson serta dapat menjadi pertimbangan dalam kebijakan peningkatan kualitas sumberdaya manusia yang nantinya akan membawa pengaruh kepada kualitas pelayanan.

\section{TINJAUAN PUSTAKA}

Kualitas pelayanan merupakan suatu driver kepuasan yang bersifat multidimensi. Tingkat kepuasan pelayanan tidak dapat dinilai beradasarkan sudut pandang perusahaan tetapi harus dipandang dari sudut pandang penilaian pelanggan. Sebab kualitas pelayanan di sekolah harus diarahkan pada kebutuhan konsumen, 
sekarang dan masa depan. Kualitas pelayanan dapat terjadi ketika harapan pelayanan terpenuhi atau terlampaui, atau sebaliknya ada kesenjangan layanan (Adeleke, 2012:1). Kepuasan dari sisi konsumen dipandang baik apabila memenuhi apa yang mereka harapkan, sebaliknya pelayanan akan dipersepsikan buruk apabila tidak memenuhi yang mereka harapkan (Kotler, 2000:45 dlm. Rinala et al, 2013).

Fandy Tjiptono (1997:24) mengungkapkan bahwa respon pelanggan kepada evaluasi terhadap kesesuaian layanan yang diberikan kepada pengguna akan mempengaruhi kepuasan atau ketidakpuasan pengguna. Kesesuaian layanan sangat terkait dengan kualitas layanan yang diberikan kepada para pengguna. Oleh sebab itu untuk mengetahui kualitas layanan maka dapat dilakukan survei kepuasan pengguna terhadap kualitas layanan.

Persepsi pengguna pelayanan akademik atas kualitas pelayanan dapat dilihat melalui hal-hal berikut:

\section{Bukti terukut (Tangibles)}

Kualitas pelayanan dalam bentuk fisik merupakan hal yang penting dalam penyelenggaraan pendidikan. Bentuk fisik (tangible) seperti gedung, peralatan, dan penampilan fisik dari seluruh karyawan merupakan atu bentuk nyata dan terlihat (tangible). Konsumen akan merasa puas jika tempat di mana ia memperoleh jasa pendidikan menarik dan nyaman (Syamsi, 2008:19). Dalam memberikan pelayanannya sarana dalam bentuk fisik adalah sarana yang harus disediakan oleh sekolah. Aspek Tangibles berkaitan dengan fasilitas sekolah, yang termasuk dalam fasilitas sekolah adalah segala sesuatu yang dipakai untuk memperlancar proses belajar mengajar seperti lahan tempat dimana sekolah didirikan, bangunan atau gedung sekolah, dan perabotan dan perlengkapan yang memadai untuk proses pembelajaran (Khasanah, 2012:138).

\section{Daya Tenggap (Responsiveness)}

Daya tanggap merupakan kemampuan para karyawan untuk membantu para pelanggan dan memberikan pelayanan dengan tanggap. Hal yang berkaitan dengan responsiveness adalah kesigapan melayani pelanggan, kecepatan menanggapi permintaan/pertanyaan, proaktif melayani pelanggan (Sancoko, 2010:47).

\section{Keandalan (Realibility)}

Kehandalan merupakan kemampuan untuk memberikan pelayanan yang dijanjikan dengan segera, akurat, memuaskan dan dapat dipercaya. Sancoko (2010:47) mengungkapkan aspek reliability terkait dengan pelaksanaan janji, pelaksanaan janji sudah akurat, dan pelaksanaan janji perbaikan atas saran sebelumnya. Menurut Radja, Supramono, dan Sulasmono (2013:85) aspek reliability merujuk kepada kemampuan untuk memberikan layanan sesuai dengan apa yang dijanjikan secara akurat dan handal.

\section{Jaminan (Assurance)}

Adanya jaminan berupa pengetahuan dan keramahan serta kemampuan untuk memberitahukan secara meyakinkan dan dapat dipercaya. Sancoko (2010:47) mengemukakan bahwa aspek assurance berkaitan dengan kompetensi pegawai yang memberikan pelayanan, kemudian sopan santun pegawai yang memberikan pelayanan, pelayanan bisa dipercaya, amanah dan jujur. 


\section{Empati (Empathy)}

Dalam empati adanya kemudahan dalam melakukan hubungan, komunikasi yang baik, perhatian pribadi, dan memahami kebutuhan pelanggan. Radja, Supramono, dan Sulasmono (2013:85) mengungkapkan bahwa aspek empathy mencakup kepedulian serta perhatian individual yang diberikan kepada para pengguna. Hal yang senada diungkapkan oleh Indrawati (2011:27) bahwa empati ditunjukkan dengan adanya perhatian yang bersifat pribadi yang diberikan kepada pengguna jasa, melakukan kontak, kemudian hubungan dan komunikasi dengan pengguna serta adanya upaya untuk memahami apa yang menjadi kebutuhan dan keinginan para pengguna.

\section{METODE PENELITIAN}

Untuk melaksanakan penelitian ini, penulis menggunakan penelitian kuantitatif khususnya survei. Populasi adalah wilayah generalisasi yang terdiri atas 75 responden. Mengingat jumlah mahasiswa STT Simpson yang tidak terlalu banyak maka dalam penelitian ini tidak akan menggunakan sampel melainkan akan diambil seluruhnya atau menggunakan populasi.

Karena variabel yang diteliti dalam penelitian ini adalah kepuasan mahasiswa maka ada satu instrumen yang akan dibuat yaitu instrumen untuk mengukur kepuasan pelayanan mahasiswa. Skala pengukuran yang akan digunakan dalam penelitian ini adalah skala kepuasan pelayanan mahasiswa model Likert dengan skala interval 1 sampai 5. Menurut Sugiyono (2012:136) skala Likert digunakan untuk mengukur sikap, pendapat, dan persepsi seseorang atau sekelompok orang tentang fenomena sosial. Penelitian ini menggunakan data valid yang dikumpulkan dari seluruh responden melalui penyebaran kuesioner kepada para mahasiswa STT Simpson Ungaran semester genap tahun ajaran 2016/2017. Teknik pengumpulan data untuk penelitian ini akan akan menggunakan angket Responden akan diberikan sperangkat pertanyaan atau pernyataan tertulis yang akan dijawab oleh mereka.

Analisis ini dilakukan untuk mengetahui tanggapan atau respon yang diberikan responden terhadap variabelvariabel penelitian.Sedangkan untuk memperoleh kesimpulan secara deskriptif, maka jawaban-jawaban tersebut kemudian ditentukan intervalnya guna memperoleh jawaban dari semua responden yang menjadi sampel dalam penelitian. Dari lima macam jawaban dalam kuesioner, diperoleh interval sebagai berikut (Junaedi, 2001): (1) Nilai jawaban 1,00 s/d 1,79=Tidak memuaskan; (2) Nilai jawaban 1,80 s/d 2,59=Kurang memuaskan; (3) Nilai jawaban 2,60 s/d 3,39=Cukup memuaskan; (4) Nilai jawaban 3,40 s/d 4,19=Memuaskan; Nilai jawaban 4,20 s/d 5,00=Sangat Memuaskan.

\section{Teknik Analisis Data}

Metode analisis data yang digunakan dalam penelitian ini adalah Analisis Deskriptif Persentase. Deskriptif Persentase ini dioleh dengan cara frekuensi dibagi dengan jumlah responden dikali $100 \%$, seperti yang dikemukanan Sudjana (2001:129) sebagai berikut:

$$
\mathrm{p}=\frac{\mathrm{f}}{\mathrm{N}} \times 100 \%
$$

Keterangan:

$\mathrm{p}=$ Persentase

$\mathrm{f} \quad=$ Frekuensi

$\mathrm{N}=$ Jumlah responden

$100 \%$ = Bilangan Tetap 


\section{HASIL DAN PEMBAHASAN}

\section{Hasil}

Berikut ini adalah hasil rata-rata
2016/2017 semester genap terhadap layanan STT Simpson, Kabupaten Semarang:

survei kepuasan mahasiswa tahun akademik

Tabel 1 Kepuasan Mahasiswa Terhadap Kualitas Layanan

\begin{tabular}{llc}
\hline No & \multicolumn{1}{c}{ Indikator } & Rerata \\
\hline Aspek Tangibel & \\
\hline 1. & Memiliki Dosen dan karyawan yang berpenampilan rapi dan sopan & $4.28 / 5.00$ \\
2. & Memiliki perpustakaan yang legkap & $4.00 / 5.00$ \\
3. & Memiliki tempat pakir yang luas & $3.92 / 5.00$ \\
4. & Memiliki ruang tunggu yang nyaman dan bersih & $3.79 / 5.00$ \\
5. & Mempunyai alat-alat laboratorium yang dapat mencukupi kebutuhan & $3.53 / 5.00$ \\
6. & Memiliki lingkungan sekolah yang bersih & $4.00 / 5.00$ \\
7. & Mempunyai materi pendukung Informasi yang menarik & $4.03 / 5.00$ \\
8. & Mempunyai kamar kecil yang mencukupi dan terjaga dengan bersih & $3.97 / 5.00$ \\
9. & Memiliki fasilitas olah raga yang mencukupi dan memadai & $4.00 / 5.00$ \\
10. & Mempunyai ruang makan mahasiswa yang bersih & $4.35 / 5.00$ \\
11. & Mempunyai ruang kelas dan ruang lainnya dengan penerangan yang baik & $4.23 / 5.00$ \\
12. & Mempunyai sarana pendukung pembelajaran & $3.99 / 5.00$ \\
13. & Memiliki ruang konseling yang rapi dan bersih & $3.79 / 5.00$ \\
14. & Memiliki halaman untuk kegiatan mahasiswa yang mencukupi dan bersih & $4.16 / 5.00$ \\
\hline
\end{tabular}

\begin{tabular}{lll}
\hline \multicolumn{2}{l}{ Aspek } & Reability \\
\hline 1. & Pelayanan untuk mahasiswa sesuai dengan waktu yang dijanjikan & $4.21 / 5.00$ \\
2. & Nomor telepon STT Simpson Ungaran mudah dihubungi & $4.43 / 5.00$ \\
3. & Mempunyai bidang konseling yang memperhatikan mahasiswanya & $4.12 / 5.00$ \\
4. & Mempunyai Dosen dan karyawan yang berkompeten & $4.19 / 5.00$ \\
5. & Memberikan pelayanan yang tidak berbelit-belit & $4.11 / 5.00$ \\
6. & Kegiatan harian dan pelayanan sekolah sesuai jadwal & $4.15 / 5.00$ \\
7. & Pelayanan Senat Mahasiswa yang mudah diikuti & $4.23 / 5.00$ \\
8. & Memiliki jaringan Internet dengan akses yang cepat & $4.05 / 5.00$ \\
9. & Pelayanan kerohanian teratur & $4.51 / 5.00$ \\
10. & Membuat dokumentasi data dengan akurat & $4.19 / 5.00$
\end{tabular}

\begin{tabular}{llc}
\hline \multicolumn{2}{l}{ Aspek } & Responsiveness \\
\hline 1. & Pelayanan Dosen dan karyawan yang tepat waktu & $4.25 / 5.00$ \\
2. & Cepat dalam menanggapi keluhan mahasiswa & $4.01 / 5.00$ \\
3. & Informasi yang diberikan mudah dimengerti & $4.23 / 5.00$ \\
4. & Kecepatan memberi pelayanan & $4.23 / 5.00$ \\
5. & Lokasi perpustakan mudah dijangkau & $4.41 / 5.00$ \\
6. & Kesediaan Dosen dan karyawan memberikan pelayanan setiap waktu & $4.19 / 5.00$ \\
7. & Mahasiswa tidak perlu menunggu lama dalam mendapatkan pelayanan dari pihak & $4.08 / 5.00$ \\
8. & Mekolah & $4.32 / 5.00$ \\
9. & Bersikap professional & $4.28 / 5.00$ \\
10. & Memberikan rasa aman kepada mahasiswa & $4.33 / 5.00$ \\
\hline Aspek & Assurance & \\
\hline 1. & Memiliki area parkir yang aman & $4.21 / 5.00$
\end{tabular}




\begin{tabular}{llc}
\hline No & \multicolumn{1}{c}{ Indikator } & Rerata \\
\hline 2. & Mempunyai ruang ibadah yang nyaman & $4.35 / 5.00$ \\
3. & Proses pembelajaran yang nyaman & $4.41 / 5.00$ \\
4. & Program sekolah sesuai dengan kurikulum pemerintah & $4.47 / 5.00$ \\
5. & Program studi yang ada menjanjikan pekerjaan yang layak & $4.47 / 5.00$ \\
6. & Lulusan sekolah dapat diterima di gereja atau melanjutkan program pendidikan lebih & $4.44 / 5.00$ \\
\hline & tinggi \\
\hline Aspek Emphaty & $4.28 / 5.00$ \\
\hline 1. & Mengutamakan kepentingan mahasiswa & $4.28 / 5.00$ \\
2. & Waktu dan jam pelayanan ekstrakurikuler sesuai dengan kebutuhan mahasiswa & $4.27 / 5.00$ \\
3. & Memberikan informasi terbaru tentang perkembangan dan pelayanan sekolah & $4.23 / 5.00$ \\
4. & Menumbuhkan kesan positif bagi setiap mahasiswa & $4.21 / 5.00$ \\
5. & Pelayanan yang sama kepada semua mahasiswa tanpa memandang status social & $4.12 / 5.00$ \\
6. & Memberikan perhatian secara khusus kepada mahasiswa dan keluarganya & $4.15 / 5.00$ \\
7. & Memahami kebutuhan setiap mahasiswa secara spesifik
\end{tabular}

Dari hasil rata survei kepuasan mahasiswa tahun akademik 2016/2017 semester genap dapat dilihat bahwa rata-rata terendah aspek ini adalah 3,53 dan rata-rata tertingginya adalah 4,35. Melihat hasil tersebut maka sesungguhnya kepuasan mahasasiswa cukup tinggi terhadap sarana dan prasarana yang disediakan oleh sekolah (STT Simpson). Meski demikian masih ada beberapa aspek yang harus ditingkatkan guna meningkatkan layanan kepada mahasiswa. Adapun layanan yang mendapatkan rata-rata tertinggi adalah memiliki ruang makan yang bersih. Sementara itu rata-rata terendah adalah memiliki alat-alat laboratorium yang dapat mencukupi kebutuhan. Melihat hasil rata-rata di atas maka dapat disimpulkan dari aspek tangibles secara keseluruhan tergolong dalam kategori memuaskan. Meski demikian mutu layanan STT Simpson hendaknya lebih meningkatkan aspek-aspek yang masih dirasa lemah untuk meningkatkan mutu layanan. Melalui table diagram diatas dapat dilihat rata-rata keseluruhan aspek tangibles adalah $(4,01 / 5,00)$ atau memuaskan

Dari hasil survei aspek reability dapat dilihat aspek tertinggi dengan skor 4,51 adalah pelayanan kerohanian teratur. Sementara itu aspek dengan skor terendah adalah memiliki jaringan internet dengan akses cepat yaitu dengan skor 4,05. Skor aspek reability rata-ratanya adalah 4.22 yang artinya layanan dari aspek ini tergolong sangat memuaskan bagi mahasiswa STT Simpson.

Sementara itu skor tertinggi pada aspek responsiveness adalah lokasi perpustakaan mudah untuk dijangkau, yaitu dengan skor 4,41 yang artinya mahasiswa sangat puas dengan layanan perpusatakaan khususnya dari sisi lokasi. Cepat dalam menanggapi keluhan mahasiswa adalah aspek responsiveness yang paling rendah, yaitu dengan skor 4,08. Meski aspek tersebut menduduki posisi terendah namun masih tergolong dalam ketegori memuaskan.

Pada aspek assurance, program sekolah sesuai dengan kurikulum pemerintah dan program studi yang ada menjanjikan pekerjaan yang layak dengan total skor 4,47 adalah 2 poin aspek assurance yang paling tinggi skornya. Sementara itu, memiliki area parkir yang aman menduduki posisi terendah dalam aspek assurance yaitu dengan skor 4,21. Apsek assurance menduduki posisi tertinggi dari aspek yang lainnya. Jika diratarata memiliki skor 4,39 (sangat memuaskan). Tentunya hal ini menjadi hal yang sangat penting bagi STT Simpson dalam melakukan 
pelayanan terhadap mahasiswa. Minimal dipertahankan atau jikalau mungkin ditingkatkan dari tahun ke tahun.

Sementara pada aspek emphaty, hasil survei menunjukkan pelayanan yang diberikan mengutamakan kepentingan mahasiswa dan waktu dan jam pelayanan ekstrakurikuler sesuai dengan kebutuhan mahasiswa adalah 2 poin yang mendapatkan skor tertinggi dari aspek empathy, yaitu dengan skor 4,28. Sementara itu skor terendah adalah memberikan perhatian secara khusus kepada mahasiswa dan keluarganya, yaitu 4,12.

Rata-rata kepuasan kepuasan mahasiswa terhadap kualitas layanan di STT Simpson dapat diperhatikan dalam gambar berikut:

Gambar 1 Rata-Rata Kepuasan Mahasiswa Terhadap Kualitas Layanan

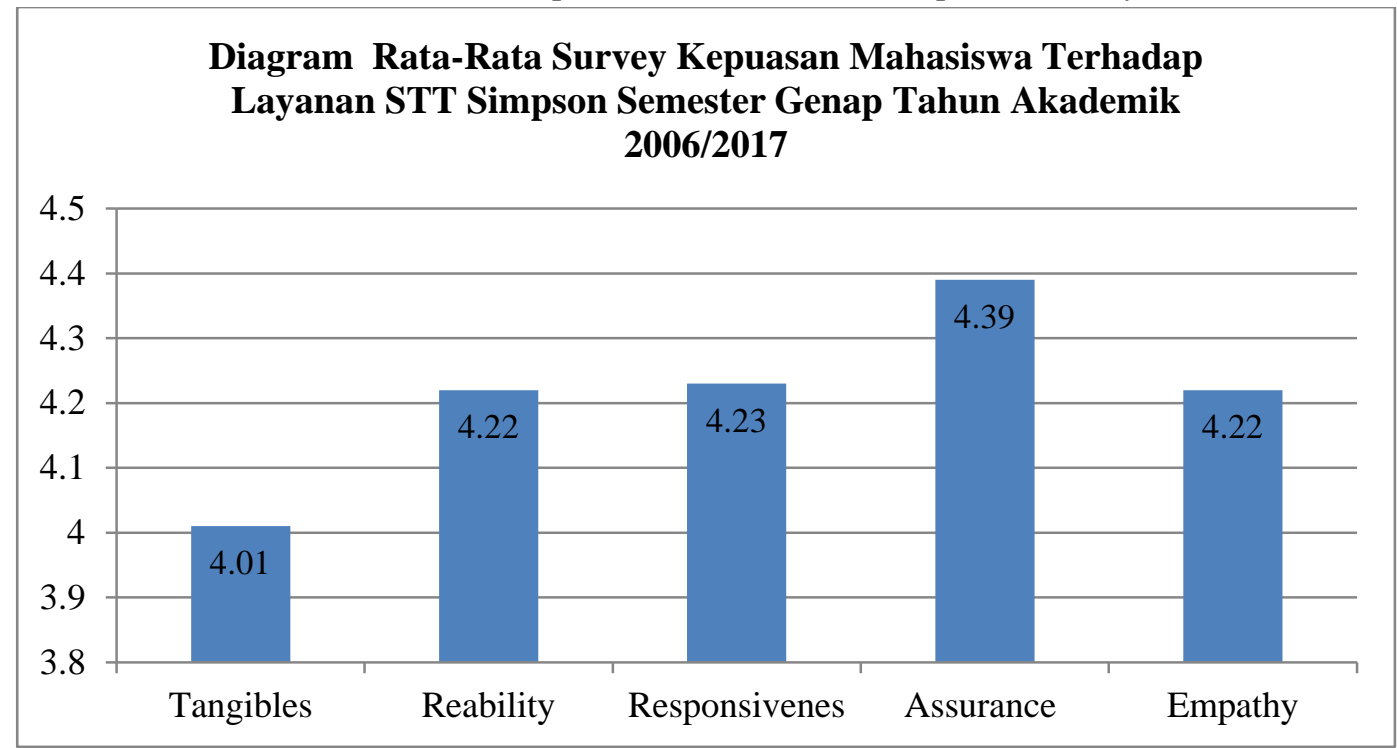

Berdasarkan data dalam tabel 1 menunjukkan bahwa tingkat kepuasan mahasiswa terhadap pelayanan yang diberikan di STT Simpson sangat baik.

Dari hasil rata survei kepuasan mahasiswa tahun akademik 2016/2017 semester genap dapat dilihat bahwa ratarata terendah aspek ini adalah 3,53 dan ratarata tertingginya adalah 4,35. Melihat hasil tersebut maka sesungguhnya kepuasan mahasiswa cukup tinggi terhadap sarana dan prasarana yang disediakan oleh sekolah (STT Simpson). Meski demikian masih ada beberapa aspek yang harus ditingkatkan guna meningkatkan layanan kepada mahasiswa. Adapun layanan yang mendapatkan rata-rata tertinggi adalah memiliki ruang makan yang bersih. Sementara itu rata-rata terendah adalah 52 memiliki alat-alat laboratorium yang dapat mencukupi kebutuhan.

Melihat hasil rata-rata di atas maka dapat disimpulkan dari aspek tangibles secara keseluruhan tergolong dalam kategori memuaskan. Meski demikian mutu layanan STT Simpson hendaknya lebih meningkatkan aspek-aspek yang masih dirasa lemah untuk meningkatkan mutu layanan. Melalui tabel diagram di atas dapat dilihat rata-rata keseluruhan aspek tangibles adalah $(4,01 / 5,00)$ atau memuaskan.

Kemudian dari hasil survei aspek reability dapat dilihat aspek tertinggi dengan skor 4,51 adalah pelayanan kerohanian teratur. Sementara itu aspek dengan skor terendah adalah memiliki jaringan internet dengan akses cepat yaitu dengan skor 4,05. Skor aspek reability rata- 
ratanya adalah 4.22 yang artinya layanan dari aspek ini tergolong sangat memuaskan bagi mahasiswa STT Simpson.

Sementara itu skor tertinggi pada aspek responsiveness adalah lokasi perpustakaan mudah untuk dijangkau, yaitu dengan skor 4,41 yang artinya mahasiswa sangat puas dengan layanan perpusatakaan khususnya dari sisi lokasi. Cepat dalam menanggapi keluhan mahasiswa adalah aspek responsiveness yang paling rendah, yaitu dengan skor 4,08. Meski aspek tersebut menduduki posisi terendah namun masih tergolong dalam kategori memuaskan.

Program sekolah sesuai dengan kurikulum pemerintah dan program studi yang ada menjanjikan pekerjaan yang layak dengan total skor 4,47 adalah 2 poin aspek assurance yang paling tinggi skornya. Sementara itu, memiliki area parkir yang aman menduduki posisi terendah dalam aspek assurance yaitu dengan skor 4,21. Apsek assurance menduduki posisi tertinggi dari aspek yang lainnya. Jika dirata-rata memiliki skor 4,39 (sangat memuaskan). Tentunya hal ini menjadi hal yang sangat penting bagi STT Simpson dalam melakukan pelayanan terhadap mahasiswa. Minimal dipertahankan atau jikalau mungkin ditingkatkan dari tahun ke tahun.

Pada aspek emphaty mengutamakan kepentingan mahasiswa dan waktu dan jam pelayanan ekstrakurikuler sesuai dengan kebutuhan mahasiswa adalah 2 poin yang mendapatkan skor tertinggi dari aspek empathy, yaitu dengan skor 4,28. Sementara itu skor terendah adalah memberikan perhatian secara khusus kepada mahasiswa dan keluarganya, yaitu 4,12 .

\section{Pembahasan}

Secara keseluruhan survei kepuasan mahasiswa tahun akademik 2016/2017 semester genap di STT Simpson dipandang cukup tinggi. Hanya terdapat beberapa penilaian yang masih belum cukup tinggi. Hasil di atas berbeda dengan penelitian Natalisha (2007:83) yang menunjukkan hasil penelitian bahwa program studi yang diteliti perlu meningkatkan kinerja dan pelayanan karena berada di bawah harapan mahasiswa. Berbeda dengan Natalisha (2007) hasil penelitian ini justru sejalan dengan penelitian yang dilakukan oleh Rahmawati (2013). Dalam penelitian yang dilakukan oleh Rahmawati (2013:52) salah satu faktor yang berkaitan dengan pelayanan yang meliputi pelayanan akademik dosen dan pelayanan akademik pegawai administrasi, tingkat kepuasannya berada dalam kategori puas. Dari hasil survei di STT Simpson, hal yang sama dengan yang ditemukan dari penelitian Rahmawati (2013) juga berada dalam kategori puas.

Dalam penelitian ini aspek assurance memperoleh skor yang paling tinggi. Hal tersebut dapat terjadi karena berkaitan dengan kompetensi pegawai yang memberikan pelayanan, kemudian sopan santun pegawai yang memberikan pelayanan, pelayanan bisa dipercaya, amanah dan jujur (Sancoko, 2010:47). Hal ini penting bagi pengembangan STT Simpson sebagai perguruan tinggi teologi yang terus meningkatkan daya saing. Peningkatan kualitas layanan khususnya fokus pada mahasiswa terus ditingkatkan di STT Simpson sejak tahun 2014 (Darmawan \& Sturiyono, 2016: 174, 176).

Aryani dan Rosinta (2010:125) menjelaskan bahwa pengguna jasa akan 
merasa puas setelah kinerja pelayanan memenuhi harapan pembeli. Hal tersebut berkaitan dengan rasa senang atau kecewa yang mempengaruhi kepuasan seseorang dan membandingkan antara apa yang diharapkan dengan apa yang diperoleh. Kotler (2005) mengungkapkan bahwa jika kinerja sesuai dengan harapan maka pengguna jasa akan menjadi puas, kemudian jika kinerja melebihi harapan maka pengguna jasa akan sangat puas.

\section{SIMPULAN}

Dari hasil analisis dan pembahasan dapat disimpulkan bahwa: (1) Kualitas layanan yang berwujud fisik secara keseluruhan memuaskan bagi mahasiswa STT Simpson, (2) Kualitas layanan Kehandalan secara keseluruhan sangat memuaskan bagi mahasiswa STT, (3) Kualitas layanan yang berupa daya tanggap STT Simpson memuaskan mahasiswa, (4) Kualitas layanan yang berupa jaminan secara keseluruhan sangat memuaskan bagi mahasiswa STT Simpson, (5) Kualitas layanan rasa perduli dan perhatian secara keseluruhan memuaskan mahasiswa STT Simpson.

Saran yang dapat diberikan dari hasil penelitian ini adalah bahwa indikator-indikator yang sudah berpengaruh terhadap kepuasan mahasiswa agar terus ditingkatkan supaya mahasiswa memperoleh kepuasan lebih tinggi lagi. Sedangkan pihak STT Simpson perlu untuk meningkatkan jaminan pelayanan bagi para mahasiswa agar kepuasan yang mereka dapat meningkat.

\section{DAFTAR PUSTAKA}

Adeleke, M.S. 2012. "Evaluating Service Quality of Higher Institutions in
Oyo State", IOSR Journal of Business and Management (IOSRJBM), Volume 1, Issue 3 (May-June 2012), www.iosrjournals.org.

Aryani, D. dan F. Rosinta. 2010. "Pengaruh Kualitas Layanan terhadap Kepuasan Pelanggan dalam Membentuk Loyalitas Pelanggan," Bisnis \& Birokrasi, Jurnal Ilmu Administrasi dan Organisasi, 17 (2), 114-126.

Darmawan, I P.A. \& Sutriyono. 2016. "Strategi Bersaing Untuk Meningkatkan Daya Saing Sekolah Tinggi Teologia Di Ungaran," Jurnal Kelola, 3 (2), 164-177.

Indrawati, Aniek. 2011. Pengaruh Kualitas Layanan Lembaga Pendidikan terhadap Kepuasan Konsumen. Jurnal Ekonomi Bisnis. 16 (1), 25-35.

Junaedi, M.F. Sheelyama, \& C. Mariiana Junaedi. 2001. "Mengukur Persepsi Harapan dan Kualitas Jasa Konsumen dengan Model Service Quality,"Jurnal Widya Manajemen, 1 (2), 96-107.

Khasanah, Nurul. 2012. "Faktor-Faktor Yang Mempengaruhi Orang Tua Dalam Pengambilan Keputusan Memilih Sekolah Dasar Swasta (SD Virgo Maria 2 dan SDIP. H. Soebandi Kecamatan Bawen Kabupaten Semarang)", Satya Widya, 28 (2), 137-146.

Kotler, Philip. 2005. Manajemen Pemasaran, jilid 1. Jakarta: Indeks.

Miyono, Noor. 2011."Kepuasan Dan Loyalitas Pelanggan Pada Sekolah Dasar Swasta Unggul Di Semarang," Dinamika Sosial Ekonomi, 7 (2), 148-163. 
Natalisa, Diah. 2007. "Survey Kepuasan Pelanggan Program Studi Magister Manajemen Universitas Sriwijaya," Jurnal Manajemen \& Bisnis Sriwijaya, 5 (9), 83-98.

Radja, N.R., Supramono, B.S. Sulasmono.2013. "Pengaruh Kualitas Layanan Atas Kepuasan Siswa Dan Dampaknya Terhadap Loyalitas Siswa Di SMK Kristen Salatiga," Satya Widya, 29 (2), 8392.

Rahmawati, Diana. 2013. "Analisis Faktor-Faktor Yang Mempengaruhi Kepuasan Mahasiswa," Jurnal Economia, 9 (1): 52-65.

Rinala, I Nyoman et al. 2013. "Pengaruh Kualitas Pelayanan Akademik Terhadap Kepuasan dan Loyalitas Mahasiswa Pada Sekolah Tinggi Pariwisata Nusa Dua Bali," $e$ Journal Program Pascasarjana Universitas Pendidikan Ganesha Program Studi Administrasi Pendidikan, 4 (1).

Sallis, Edward. 2012. Total Quality Managemenin Education. Yogyakarta: ICRSD.

Sancoko, Bambang. 2010.“Pengaruh Remunerasi terhadap Kualitas Pelayanan Publik,"Bisnis \& Birokrasi, Jurnal Ilmu Administrasi dan Organisasi, 17 (1), 43-51.

Sudjana. 2001. Methode Statistika. Bandung: Alfabeta.

Sugiyono. 2012. Metode Penelitian Kuantitatif, Kualitatif dan Kombinasi. Bandung: Alfabeta.

Syafaruddin. 2012. Pendidikan dan Pemberdayaan Masyarakat. Medan: Perdana Publishing.

Syamsi. 2008. "Pengaruh Kualitas Pelayanan Jasa Terhadap
Kepuasan Konsumen Pada Siswa Bimbingan dan Konsultasi Belajar Al Qolam Bandarlampung," Jurnal Ekonomi \& Pendidikan, 5 (1), 18-36.

Tjiptono, Fandi. 1997. Strategi Pemasaran. Yogyakarta: Penerbit Andi. 